\title{
Latvijas valsts pārvaldes cilvēkresursu vadības politikas novērtējums un pilnveidošanas iespējas
}

\author{
Iveta Baltina ${ }^{1}$, Maija Senfelde ${ }^{2},{ }^{1-2}$ Riga Technical University
}

\begin{abstract}
Kopsavilkums. Raksta mērḳis ir noskaidrot Latvijas valsts pārvaldes darbinieku viedokli par esošo situāciju valsts pārvaldes cilvēkresursu politikas izstrādes un ieviešanas jomā un parādīt valsts pārvaldē darba organizēšanas un pilnveidošanas iespējas. Pētījumā tika izmantotas tādas metodes kā dokumentu analīze un aptauja. Apkopotā informācija liecina, ka valsts pārvaldē vāji attīstīta stratēgeiskā cilvēkresursu vadība, kas noved pie formālas personāla vadības funkciju īstenošanas. Pašlaik iestādēs vāji izmanto dažādus cilvēkresursu plānošanas, vadības un motivācijas rīkus kas rada lielu kadru mainību un ietekmēe iestāžu darba rezultātus un produktivitāti. Kā viens no risinājumiem situācijas uzlabošanai tiek piedāvāta attālinātā darba ieviešana valsts pārvaldē.
\end{abstract}

Atslēgas vārdi: valsts pārvalde, stratēgiskāā cilvēkresursu vadība, attālinātais darbs.

\section{IEVADS}

Situācijā, kad pasaule strauji mainās un nākotnes darba perspektīvu arvien vairāk ietekmē tādi faktori kā globalizācija, tehnologiju attīstība un izmaiņas darba tirgū, organizāciju sniegums lielā mērā būs atkarīgs no to elastības un spējas pielāgoties straujajām izmaiṇām. Šie faktori ietekmē arī valsts pārvaldes darbu, jo valsts pārvaldes sniegums lielā mērā ir atkarīgs tieši no ierēdṇu un darbinieku darba rezultātiem. OECD veiktais pētījums parāda, ka daudzās OECD valstīs šobrīd ir vērojama valsts pārvaldes darbinieku krīze. Tādēḷ daudzu valstu valdības mēgina modernizēt valsts pārvaldes darbinieku nodarbinātības politikas [1].

Tā kā jebkuras organizācijas galvenais virzītājspēks ir cilvēks, tad jaunas problēmas un strauji mainīgais darba tirgus, tāpat kā jaunas vadības idejas, ir sekmējušas būtiskas izmaiñas valsts pārvaldes darbinieku vadības pasākumu modernizēšanā pēdējo divu gadu desmitu laikā. Tomēr līdz šim notikušās darbības ir vairāk uzskatāmas par dažādu nodarbinātības instrumentu piemērošanu specifisku problēmu risināšanai. OECD pētījumā ir secināts, ka lielāku uzmanību jāpievērš augošajam modernas valsts pārvaldes zināšanu un iemaņu pieprasījumam un pieaugošajām grūtībām augsta līmeņa darbinieku piesaistei un noturēšanai darbā valsts pārvaldē [1]. Tas liek secināt, ka nākotnē it îpaši liela nozīme būs tādiem cilvēkresursu vadības pasākumiem, kuri ir vērsti uz darbinieku vadību, motivēšanu un attīstīšanu darbam 2020.-2050.gadā, kā arī jaunu darba formu un metožu ieviešanai valsts pārvaldē.

Situācijā, kad tiek runāts par efektīvu valsts pārvaldi, būtiski ir saprast, kāda pašlaik ir Valsts pārvaldes cilvēkresursu politika Latvijā un vai esošajos darbinieku attīstības plānošanas un ieviešanas pasākumos tiek nuemtas vērā straujās izmaiṇas ekonomikā un darba tirgū.
Līdz šim veiktie pētījumi un zinātniskā literatūra par stratēǵisko cilvēkresursu vadību sniedz nepārprotamus pierādījumus, ka plaši definētām un augsti attīstītām cilvēkresursu vadības sistēmām ir pozitīva ietekme uz organizācijas sniegumu [2].

Tā kā viens no organizācijas sniegumu ietekmējošiem faktoriem ir darbinieku motivācija, tad š̄ raksta mērksis ir novērtēt valsts pārvaldē strādājošo viedokli par cilvēkresursu vadības politikas plānošanu un ieviešanu valsts pārvaldē kopumā, kā arī novērtēt darbinieku apmierinātību ar darbu konkrētajā iestādē.

\section{DARBINIEKU APMIERINĀTĪBU IETEKMĒJOŠIE FAKTORI UN TO NOVĒRTĒŠANAS INSTRUMENTI}

Chanda et al. (2009) norāda, ka stratēgiiskās cilvēkresursu vadības integrācijas ietekme uz organizācijas sniegumu var tikt mērīta ar finanšu un nefinanšu rādītājiem. Viens no nefinanšu rādītājiem, kas tiek izmantots, lai novērtētu organizācijas sniegumu, ir darbinieku apmierinātība.

Zinātnieki ir atklājuši, ka apmierināti darbinieki vairāk savā darbā iegulda zināšanas (Janz \& Prasarnphanich, 2003), uzlabo sniegumu (Judge et.al.,2001) un ir radošāki un atvērtāki sadarbībai. Tāpat tiek apgalvots, ka apmierinātiem darbiniekiem ir augstāka motivācija, ir augstāk attīstīta morāle un viņi strādā daudz un efektīgāk. Bez tam apmierināti darbinieki ir vairāk orientēti uz kvalitāti un uzlabojumiem (Matzler et.al., 2004) [3].

Līdz šim veiktie pētījumi par darbinieku apmierinātību ar darbu akcentē vairākus faktorus, kuri ietekmē darbinieku apmierinātību. 1.tabulā ir apkopta informācija par pētījumiem, kuros ir analizēta tādu faktoru kā atlīdzība un taisnīgums, autonomija jeb brīvība darbā, identitāte un korporatīvais tēls un savstarpējo attiecību ietekme uz darbinieku apmierinātību.

1. TABULA

DARBINIEKU APMIERINĀTĪBU IETEKMĒJOŠIE FAKTORI [PĒC 3]

\begin{tabular}{|l|l|}
\hline Faktori & Pētījumi \\
\hline Atlīdzība un taisnīgums & Maslow 1954, Eskildsen et al., 2004, \\
& Liou et al., 1990; Ting, 1997; Barber \\
& et al.,1992; Daley, 1986; Emmert un \\
& Taher, 1992; Mertensen un \\
& Gronholdt 2001; Nachmias, 1988. \\
\hline Autonomija jeb brīvība darbā & Henderson \& Lee, 1992; Manz, \\
& $1992 ;$ Manz \& Sims, 1980; Campion \\
& et al., 1993; Conger\& Kanungo, \\
& $1988 ;$ Nonaka\&Takeuchi, 1995; \\
& Schulz, 2001. \\
\hline Identitāte un korporatīvais tēls & Gronholdt et al., 2000, Kristensen et \\
& al., 2000. \\
\hline Savstarpējās attiecības & Eskildsen et al., 2004; Martensen \& \\
& Gronholdt, 2001; Herzberg 1966. \\
\hline
\end{tabular}


Šie pētījumi, piemēram, parāda, ka pozitīvas attiecības starp padotajiem un vadītājiem veicina augstāku apmierinātības lìmeni, samazina stresu un uzlabo darbinieku sniegumu. Savukārt augstāks autonomijas līmenis uzlabo darba rezultātus. Tāpat autonomija tiek uzskatīta par ievērojamu zināšanu apmainnas koordinatoru starp organizācijas cilvēkiem un nodaļām. Tādēl var uzskatīt, ka autonomijai ir pozitīva ietekme uz darbinieku apmierinātību. Tāpat veiktie pētījumi pierāda, ka organizācijas tēlam ir pozitīva ietekme uz apmierinātību ar darbu. Savukārt savstarpējās attiecības, kā arī darbinieku vēlme pēc atzīšanas, novērtēšanas, atbildības un sasniegumiem pozitīvi ietekmē darbinieku apmierinātību un darba rezultātus[3].

Praksēe, lai novērtētu darbinieku apmierinātību, tiek izmantotas dažādas metodes un rādītāji. Viens no tiem, piemēram, ir darbinieku apmierinātības indekss (Employee Satisfaction Index (ESI)). Indeksa noteikšanai tiek izmantota aptaujas metode, kur katram jautājumam tiek piemērota novērtēšanas skala no 1 līdz 5 , kur 1 nozīmē pilnībā nepiekrītu un 5 - pilnībā piekrītu [4].

Vēl viens rādītājs, kas tiek izmantots, lai izmērītu darbinieku apmierinātību ar darbu, ir darba apmierinātības indekss (Index of Job Satisfaction (IJS)) (Brayfield \& Rothe, 1951). Ar šī indeksa palīdzību ir iespējams izmērīt darbinieku apmierinātîbu ar darbu vai darbvietu. Lai to izdarîtu, atbildes tiek novērtētas no 1 līdz 7 punktiem, kur līdzīgi kā iepriekšejēā rādītāja novērtēšanā, 1 nozīmē pilnībā nepiekrītu, bet 7 pilnībā piekrītu [5].

Šo indeksu aprēķināšanai tiek izmantota Lykert tipa skala, kura tika izveidota, lai izmērītu cilvēku attieksmi pret vienu vai citu apgalvojumu [6].

\section{PēTĩJuma Metodolog̣iJA}

Pētījuma mērķis ir novērtēt esošo valsts pārvaldes cilvēkresursu vadības politiku Latvijā un tās ietekmi uz darbinieku apmierinātību ar darbu. Pētījuma ietvaros tika izvirzīti šādi jautājumi:

1) Kā valsts pārvaldes darbinieki novērtē valsts pārvaldes cilvēkresursu attīstības politiku?

2) Kā valsts pārvaldes darbinieki ir apmierināt ar darbu konkrētajā iestādē?

3) Kādi faktori ietekmē darbinieku apmierinātību ar darbu konkrētajā iestādē?

4) Kā darbinieki novērtē tādas modernas darba organizācijas formas kā attālinātais darbs attīstības iespējas valsts pārvaldēe

Lai sniegtu atbildes uz izvirzītajiem jautājumiem, pētījumā tiek izmantotas tādas kvalitatīvās pētījuma metodes kā dokumentu analīze un aptauja. Aptaujas rezultātu apkopošanai un novērtēšanai tika izmantota Lykert tipa skala, kur katrs no apgalvojumiem jānovērtē no 1 līdz 5 punktiem, kur 1 - pilnībā nepiekrītu, 5 piln̄īā piekrītu. Tā kā aptaujas mērḳis bija novērtēt valsts pārvaldē strādājošo apmierinātību ar cilvēkresursu vadības politikas plānošanu un ieviešanu valsts pārvaldē kopumā, kā arī novērtēt darba motivējošos faktorus konkrētajā iestādē, tad aptaujas anketa tika iedalīta divās daḷās:

1. Valsts pārvaldes cilvēkresursu politikas plānošana un ieviešana, kurā respondentiem skalā no 1 līdz 5 bija jānovērtē dažādi ar valsts pārvaldes cilvēkresursu politikas plānošanu un ieviešanu saistīti aspekti.

2. Apmierinātība ar darbu konkrētajā iestādē, kurā respondentiem skalā no 1 līdz 5 punktiem bija jānovērtē dažādi darba izpildi veicinošie un kavējošie aspekti šādās jomās:

2.1. iestādes līderība un plānošana;

2.2. iestādes darba organizācija un informācijas aprite;

2.3. iestādes kultūra un iekšējā komunikācija;

2.4. darba saturs un rezultāti;

2.5. darba vide;

2.6. attiecības ar tiešo vadītāju;

2.7. cilvēkresursu plānošana un attīstība;

2.8. darba atalgojums un tā sasaiste ar rezultātiem;

2.9. attālinātais darbs kā darba organizācijas forma.

Darbinieku viedokḷa analīzei un atspoguḷošanai tika izmantoti astoṇi faktori, kuri ietekmē darbinieku apmierinātību ar darbu. 2. tabulā ir atspoguḷota darbinieku viedokḷa novērtēšanai izmantotie faktori un kopējais jautājumu skaits.

2.TABULA

DARBINIEKU VIEDOKḶA NOVĒRTĒŠANAI IZMANTOTIE FAKTORI UN KOPĒJAIS JAUTĀJUMU SKAITS

\begin{tabular}{|l|l|}
\hline Faktori & Jautājumu skaits \\
\hline Iestādes līderība un plānošana (a) & $2.1 .1 .-2.1 .10$. (10 apgalvojumi) \\
\hline $\begin{array}{l}\text { Iestādes darba organizācija un } \\
\text { informācijas aprite (b) }\end{array}$ & $2.2 .1 .-2.2 .8$. (8 apgalvojumi) \\
\hline $\begin{array}{l}\text { Iestādes kultūra un iekšējā } \\
\text { komunikācija (c) }\end{array}$ & $2.3 .1 .-2.3 .9$. (9 apgalvojumi) \\
\hline Darba saturs un darba rezultāti (d) & $2.4 .1 .-2.4 .6 .(6$ apgalvojumi) \\
\hline Darba vide (e) & $2.5 .1 .-2.5 .6 .(6$ apgalvojumi) \\
\hline $\begin{array}{l}\text { Attiecības ar tiešo vadītāju (f) } \\
\text { Cilvēkresursu plānošana un attīstība } \\
\text { (g) }\end{array}$ & $2.7 .1 .-2.7 .11$. (11 apgalvojumi) \\
\hline $\begin{array}{l}\text { Darba atalgojums un tā sasaiste ar } \\
\text { rezultātiem (h) }\end{array}$ & $2.8 .1 .-2.8 .6 .(6$ apgalvojumi) \\
\hline
\end{tabular}

Lai novērtētu darbinieku viedokli par iepriekš minētajiem faktoriem, tika izmantotas šādas formulas:

$F(x 1)=\left(1 *_{n} 1+2 *_{n} 2+3 *_{n} 3+4 *_{n} 4+5 * n 5\right) / n$,

Kur F(x1) - attiecīgā faktora jautājuma novērtējums, $\mathrm{n} 1$ - respondentu skaits, kuri apgalvojumu ir novērtējuši ar 1, n2 - respondentu skaits, kuri apgalvojumu ir novērtējuši ar 2, n3 - respondentu skaits, kuri apgalvojumu ir novērtējuši ar 3, n4 - respondentu skaits, kuri apgalvojumu ir novērtējuši ar 4, n5 - respondentu skaits, kuri apgalvojumu ir novērtējuši ar 5, $\mathrm{n}$ - kopējais respondentu skaits.

$F(y)$ vid $=(F(x 1)+F(x 2)+\ldots \ldots \ldots \ldots . . F(x n)) / n(x)$, 
kur $\mathrm{F}(\mathrm{y})$ - attiecīgā faktora vidējais novērtējums, n(x) kopējais faktora novērtēšanā izmantotais jautājumu skaits.

Savukārt, lai sniegtu atbildi uz jautājumu, par tādas darba organizācijas formas kā attālinātais darbs attīstības iespējām valsts pārvaldē, darbiniekiem kopumā bija jānovērtē septiņi apgalvojumi no 2.9.1. līdz 2.9.7. Pētījumā šie apgalvojumi tiek izmantoti, lai noskaidrotu darbinieku viedokli par attālinātā darba kā darba organizācijas formas ieviešanas potenciālu valsts pārvaldē, bet netiek analizēts kā apmierinātību ar darbu ietekmējošais faktors.

\section{PĒTĪJUMA REZULTĀTI}

\section{A. Sociāli demogrāfiskais profils}

3.tabulā ir apkopoti dati par aptaujā piedalījušos respondentu sociāli demogrāfisko profilu.

\section{TABULA}

RESPONDENTU SOCIĀLI DEMOGRĀFISKAIS PROFILS

\begin{tabular}{|l|l|}
\hline Respondenta profils & Skaits \\
\hline Kopējais respondentu skaits & 1253 \\
\hline Vīrieši & 297 \\
\hline Sievietes & 951 \\
\hline Bez dzimuma norādes & 5 \\
\hline Nepilnīgi aizpildītas anketas & 9 \\
\hline Atbilstošas anketas & 1244 \\
\hline $\begin{array}{l}\text { Speciālists (piemēram, vecākais referents, projektu vadītājs, } \\
\text { juriskonsults, konsultants u.c.) }\end{array}$ & 879 \\
\hline $\begin{array}{l}\text { Vidējā līmeņa vadītājs (nodąas vadītājs, nodaḷas vadītāja } \\
\text { vietnieks, departamenta direktora vietnieks) }\end{array}$ & 307 \\
\hline $\begin{array}{l}\text { Augsta līmeņa vadītājs (departamenta direktors, valsts } \\
\text { sekretāra vietnieks, valsts sekretārs) }\end{array}$ & 48 \\
\hline Vidējais vecums & 39,5 gadi \\
\hline
\end{tabular}

Kopumā aptaujā piedalījās un anketas aizpildīja 1253 respondenti, no tiem 297 vīrieši, 951 sieviete. Pieci respondenti nebija norādījuši dzimumu un deviņas anketas nebija pilnībā aizpildītas. Tādējādi kopumā par atbilstošām un datu apkopošanā izmantojamām tika atzītas 1244 anketas. Respondentu vidējais vecums - 39,5 gadi. Sadalījumā pa amatu kategorijām vislielākais respondentu skaits veido speciālistu līmeni - 71\%. Attiecīgi vidējā līmeña vadītāji $25 \%$ un augsta līmeņa vadītāji - tikai $4 \%$ jeb 48 respondenti (skat 3.tab.).

1.attēlā ir apkopota informācija par respondentu valsts pārvaldē un attiecīgajā iestādē nostrādāto laiku.

$$
\begin{aligned}
& \text { Cik ilg̣i Jūs strādājat valsts pārvaldê: } \\
& \text { Cik ilọi Jus stradajat šaja icstadc: }
\end{aligned}
$$

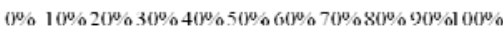

$$
\begin{aligned}
& \text { | }<1 \text { gads }=1 \text { to } 3 \text { gadi }=4 \text { to } 7 \text { gadi } \quad 7 \text { to } 11 \text { gadi }=11 \text { gadi }
\end{aligned}
$$

1.att. Valsts pārvaldē un iestādē nostrādātais laiks (n=1244)

Analizējot respondentus pēc nostrādātā laika iestādē un valsts pārvaldē, ir redzams, ka vislielāko īpatsvaru - $32 \%$, veido tie respondenti, kuri konkrētajā iestādē strādā jau 4-7 gadus, tomēr, analizējot valsts pārvaldē kopumā nostrādāto laiku, ir redzams, ka vislielākais atbildējušo skaits ir starp tiem darbiniekiem, kuri valsts pārvaldē strādā vairāk kā 11 gadus t.i., $38 \%$ (skat.1.attēlu). 4.tabulā ir apkopota informācija par respondentu skaitu atbilstoši atalgojumam.
4.TABULA

RESPONDENTU SKAITS ATBILSTOŠI ATALGOJUMAM

\begin{tabular}{|l|l|l|}
\hline $\begin{array}{l}\text { Amata alga pirms nodokḷu } \\
\text { nomaksas }\end{array}$ & $\begin{array}{l}\text { Respondentu } \\
\text { skaits }\end{array}$ & ippatsvars, \% \\
\hline$<500 \mathrm{LVL}$ & 455 & 36,4 \\
\hline $500-800 \mathrm{LVL}$ & 546 & 44,3 \\
\hline $801-1000 \mathrm{LVL}$ & 147 & 11,8 \\
\hline $1001-1200 \mathrm{LVL}$ & 67 & 5,4 \\
\hline$>1200 \mathrm{LVL}$ & 29 & 2,4 \\
\hline
\end{tabular}

Sadalījumā pēc amata algas pirms nodokḷu nomaksas vislielākais respondentu skaits ir starp tiem darbiniekiem, kuri saṇem 500 līdz 800 LVL mēnesī pirms nodokḷu nomaksas, t.i., 44\%. Nākamā kategorija ir tie darbinieki, kuri saņem mazāk kā 500 LVL mēnesī pirms nodokḷu nomaksas, t.i., 36\%. Savukārt vismazāk respondentu - 2\% - ir starp tiem atbildētājiem, kuri saṇem vairāk kā 1200 LVL mēnesī pirms nodokḷu nomaksas.

\section{B. Respondentu viedoklis par cilvēkresursu politikas plānošanu un ieviešanu valsts pārvaldē}

2. attēlā ir atspogul̦ots valsts pārvaldes darbinieku viedoklis par dažādiem ar valsts pārvaldes cilvēkresursu vadības politikas plānošanu un ieviešanu saistītiem aspektiem. Atbildot uz jautājumu par mērkstiecīgu cilvēkresursu politikas plānošanu un ieviešanu, $60 \%$ respondentu vai nu pilnībā nepiekrīt šādam apgalvojumam (attiecīgi 16\%), vai vairāk nepiekrīt nekā piekrīt 44\%. Pozitīivi par šo jautājumu izsakās 20\% respondentu (attiecīgi vairāk piekrīt nekā nepiekrīt $18 \%$ un pilnībā piekrīt $2 \%$ respondentu), bet $20 \%$ respondentu viedoklis dalās, jo viņi ne piekrīt, ne nepiekrīt šādam apgalvojumam. Tāpat lielākajai daļai respondentu nav skaidrs institucionālais un atbildību dalījums valsts pārvaldes cilvēkresursu politikas plānošanas un ieviešanas jomā. Attiecīgi apgalvojumu - Ir skaidrs institucionālais un atbild̄̄bu dalījums valsts pārvaldes cilvēkresursu politikas plānošanas un ieviešanas jomā darbinieki ir novērtējuši šādi: kopumā ar pilnībā nepiekrītu vai vairāk nepiekrītu nekā piekrītu uz šo jautājumu ir atbildējuši $50 \%$ respondentu. Savukārt pārējo 50\% respondentu atbildes sadalās attiecīgi 26\% - ne piekrīt, ne nepiekrīt, 21\% - vairāk piekrīt nekā nepiekrīt un tikai 3\% pilnībā piekrīt. Novērtējot esošās karjeras izaugsmes iespējas, tiek norādīts, ka tās nenodrošina labāko darbinieku noturēšanu. Lielākais vairums respondentu arī norāda, ka esošie atlases pasākumi nenodrošina labāko un kvalificētāko darbinieku atlasi. Vairāk nekā puse jeb $60 \%$ respondentu uzskata, ka valsts pārvaldē vairāk tiek īstenotas personāla lietvedības funkcijas nekā cilvēkresursu vadība. Tāpat vairāk nekā puse jeb 52\% respondentu uzskata, ka civildienestā strādāt nav prestiži. Vairāk piekrīt nekā nepiekrīit, vai pilnībā piekrīt apgalvojumam, ka civildienestā strādāt ir prestiži tikai $20 \%$ respondentu. Lūdzot novērtēt apgalvojumu, ka civildienests ir vērsts uz sodīšanas funkciju īstenošanu, atbildes sadalās šādi: pilnībā nepiekrīi 14\%, vairāk piekrīt nekā nepiekrīt 29\%, ne piekrīt, ne nepiekrīt 31,2\%, vairāk piekrīt nekā nepiekrīt $22 \%$ un pilnībā piekrīt $5 \%$ respondentu. Arī vairāk kā 1/3 daļa jeb 45\% respondentu valsts pārvaldes darbinieku iespējas regulāri pilnveidot profesionālās zināšanas novērtē negatīvi. Tomēr $37 \%$ respondentu tomēr uzskata, ka valsts pārvaldes darbiniekiem ir iespējas regulāri 
Esošās karjeras izaugsmes iespējas nodrošina labāko darbinieku noturēšanu valsts pārvaldē

Civildienests ir vērsts uz sodīšanas funkciju istenošanu

Civildienestā strādāt ir prestiži

Valsts pārvaldē vairāk tiek îstenotas personāla lietvedības funkcijas nekā cilvēkresursu vadība

Ir skaidrs institucionālais un atbildību dalījums valsts pārvaldes cilvēkresursu politikas...

Valsts pārvaldē tiek nodrošināta mērktiecīga cilvēkresursu politikas plānošana un ieviešana

3 - Ne piekrītu, ne nepiekrītu

- 5 - Pilnībā piekrîtu

2.att. Cilvēkresursu politikas plānošanas un ieviešanas novērtējums (n=1244).

pilnveidot profesionālās zināšanas. Savukārt uz jautājumu, vai piedāvātie profesionālās izaugsmes pasākumi nodrošina konkrētā darbinieka profesionālo izaugsmi, atbildes sadalās šādi: pilnībā nepiekrīt 20\%, vairāk nepiekrīt nekā piekrīt $28 \%$, ne piekrīt, ne nepiekrīt $22 \%$, vairāk piekrīt nekā nepiekrīt $24 \%$ un pilnībā piekrīt $6 \%$ respondentu. Vairāk kā puse jeb 58\% respondentu uzskata, ka informācija par valsts pārvaldē nodarbinātajiem ir pietiekama un pieejama. Tomēr, atbildot uz jautājumu, vai pārvaldes darbinieku mainība tiek regulāri apkopota un analizēta, noraidoši atbild $40 \%$ respondentu. Turklāt 1/3 dalı respondentu jeb 37\% tam ne piekrīt, ne nepiekrīt. Lielākais vairums jeb 53\% respondentu uzskata, ka valsts pārvaldē esošie cilvēkresursu atlases pasākumi nenodrošina labāko un kvalificētāko darbinieku atlasi. Tādējādi, analizējot respondentu atbildes uz jautājumiem, kas saistīti ar cilvēkresursu politikas plānošanas un ieviešanas

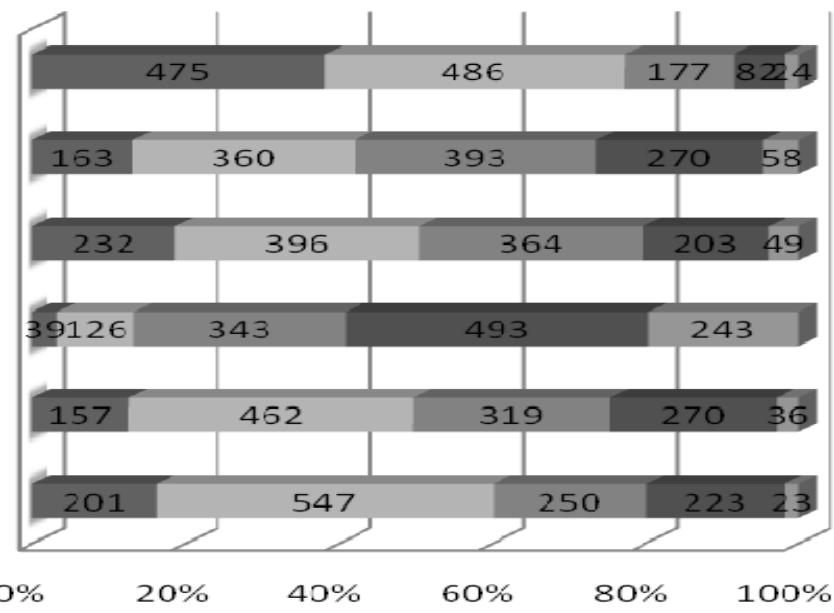

- 2 - Vairāk nepiekrītu kā piekrītu

- 4 - Vairāk piekrītu kā nepiekrītu

aspektiem, jāsecina, ka situācija nav apmierinoša, jo vairāk kā $50 \%$ respondentu situāciju vairāk vērtē negatīvi nekā pozitīivi. Aptaujas rezultāti liecina, ka valsts pārvaldē nenotiek mērķtiecīga cilvēkresursu politikas plānošana un ieviešana, darbiniekiem nav skaidrs institucionālais un atbildību dalījumus šajā jomā. Lielākais vairums respondentu uzskata, ka izveidotā civildienesta sistēma nav efektīva un nenodrošina valsts pārvaldes darba produktivitāti un kvalitāti. Darbiniekiem nav skaidra atlīdzības politika, tāpat viṇi uzskata, ka valsts pārvaldē netiek nodrošināta taisnīga un saprotama sociālo garantiju sistēma. Lai gan lielākā dal̦a respondentu uzskata, ka informācija par valsts pārvaldē nodarbinātajiem ir pietiekama un pieejama, tomēr lielākais vairums neuzskata, ka informācija par darbinieku mainību tiek regulāri apkopota un analizēta. 3.attēlā ir atspoguļots valsts pārvaldes darbinieku viedoklis par atalgojuma sasaisti ar darba rezultātiem.

Valsts pārvaldē tiek nodrošināta taisnīga un saprotama sociālo garantiju sistēma

Valsts pārvaldes atlīdzības politika nodrošina līdzīgu darba samaksu par..

Es varētu raksturot valsts pārvaldes darbu ka uz rezultatiem orientetu

Izveidotā civildienesta sistēma ir efektīva un nodrošina valsts pārvaldes darba...

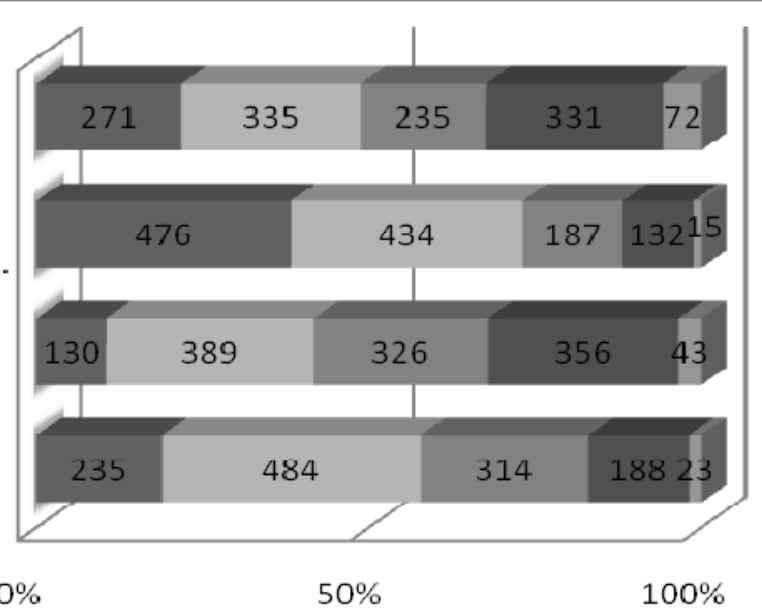

1- Pilnībā nepiekrītu

2 - Vairāk nepiekrītu kā piekrītu 3 - Ne piekrītu, ne nepiek rītu 4 - Vairāk piekrītu kā nepiekrītu 5 - Pilnībā piekrītu 
Vairāk kā $50 \%$ respondentu uzskata, ka izveidotā civildienesta sistēma nenodrošina valsts pārvaldes darba produktivitāti un kvalitāti. Tikai $17 \%$ respondentu to vērtē pozitīvi. Tomēr valsts pārvaldes darba orientācija uz rezultātiem tiek vērtēta nedaudz pozitīvāk. Pilnībā nepiekrīt vai vairāk nepiekrīt, nekā piekrīit apgalvojumam, ka valsts pārvaldes darbs ir orientēts uz rezultātiem, $41 \%$ respondentu. Salīdzinoši liels respondentu îpatsvars $27 \%$ ne piekrīt, ne nepiekrīt šādam apgalvojumam, un pozitīvs vērtējums šajā jautājumā ir $\sim 1 / 3$ daļai jeb $31 \%$ respondentu. Lielākais vairums respondentu vairāk kā $2 / 3$ negatīvi vērtē valsts pārvaldes atlīizības politiku. Attiecīgi $73 \%$ respondentu uzskata, ka valsts pārvaldes atlīdzības politika nenodrošina līdzīgu darba samaksu par līdzīgu pienākumu veikšanu dažādās iestādēs. Gandrīz 1/2 respondentu jeb 48\% nevar piekrist, ka valsts pārvaldē tiek nodrošināta taisnīga un saprotama sociālo garantiju sistēma. Tomēr $32 \%$ respondentu izsakās par to pozitīvi. Tāpat l̦oti negatīvi tiek vērtētas karjeras iespējas. $77 \%$ respondentu uzskata, ka esošās karjeras izaugsmes iespējas nenodrošina labāko darbinieku noturēšanu valsts pārvaldē.

\section{Darbinieku apmierinātība ar darbu konkrētajā iestādē}

4. attēlā ir grafiski atspoguḷots apmierinātības ar darbu konkrētajā iestādē vidējais faktoru novērtējums. Apkopotā informācija par darbinieku apmierinātību ar darbu konkrētajā iestādē liecina, ka no visiem astoņiem novērtētajiem faktoriem, visaugstāk (ar vidējo vērtību 3,71(F (d) vid) tiek novērtēts faktors (d) - darba saturs un darba rezultāti.

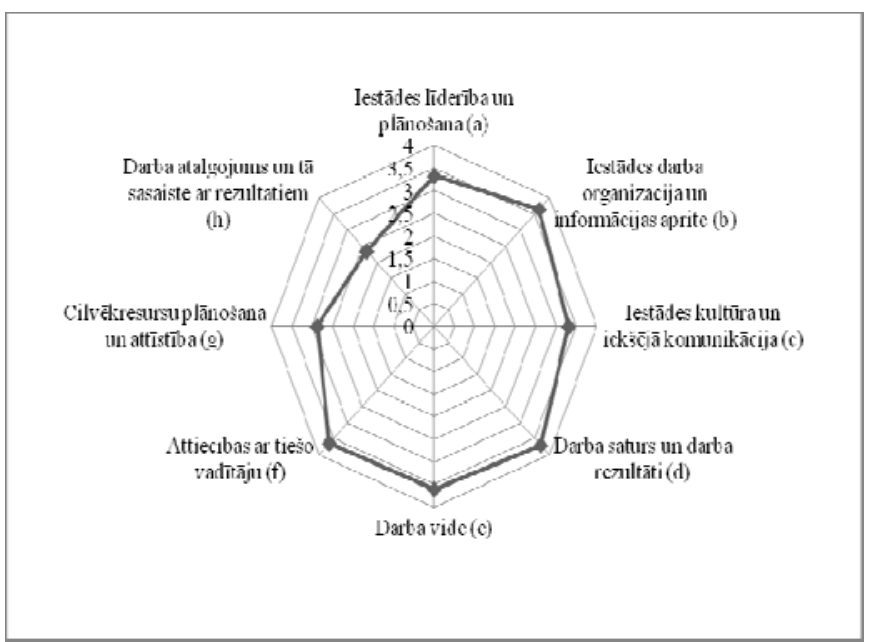

4.att. Faktoru vidējā vērtība F (a,b,c,d,e,f,g,h)vid.

Kā nākamais visaugstāk novērtētais faktors jāmin iestādes darba organizācija un iekšējā komunikācija (b) ar vidējo vērtību 3,66. Tad seko attiecības ar tiešo vadītāju (f) 3,65, darba vide (e) 3,60, iestādes līderība un plānošana (a) 3,33 un iestādes kultūra un iekšējā komunikācija (c) 3,31. Viszemāk valsts pārvaldes darbinieki savās iestādēs vērtē tādu faktoru kā cilvēkresursu plānošana un attīstība (g) ar vidējo vērtību 2,88 un darba atalgojums un tā sasaiste ar rezultātiem (h) ar vidējo vērtību 2,35.

5.tabulā ir atspoguḷota informācija par visaugstāk un viszemāk novērtētajiem apgalvojumiem katrā faktoru grupā.

5.TABULA

DARBINIEKU VIEDOKLI ATSPOGULOJOŠO FAKTORU VISAUGSTĀK UN VISZEMĀK NOVĒRTĒTIE APGALVOJUMI

\begin{tabular}{|c|c|c|c|c|}
\hline Faktora nosaukums & Visaugstāk novērtētais apgalvojums & $\begin{array}{c}\text { Apgalvojuma } \\
\text { vērtība }\end{array}$ & Viszemāk novērtētais apgalvojums & $\begin{array}{c}\text { Apgalvojuma } \\
\text { vērtība }\end{array}$ \\
\hline Iestādes līderība un plānošana (a) & $\begin{array}{l}\text { No darbiniekiem iestādē tiek prasīta } \\
\text { atbildība par rezultātiem }\end{array}$ & 4,17 & $\begin{array}{l}\text { Iestādē ir izstrādāta skaidra personāla } \\
\text { politika }\end{array}$ & 2,86 \\
\hline $\begin{array}{l}\text { Iestādes darba organizācija un } \\
\text { informācijas aprite (b) }\end{array}$ & $\begin{array}{l}\text { Ar darba izpildi saistîtie uzdevumi ir } \\
\text { saprotami }\end{array}$ & 3,96 & $\begin{array}{l}\text { Iestādē izstrādātā kārtība, instrukcijas, } \\
\text { noteikumi palīdz man efektīvi pildīt } \\
\text { tiešos darba pienākumus }\end{array}$ & 3,48 \\
\hline $\begin{array}{l}\text { Iestādes kultūra un iekšējā } \\
\text { komunikācija (c) }\end{array}$ & Esmu apmierināts ar saviem kolēǵiem & 4,03 & $\begin{array}{l}\text { Pret visiem darbiniekiem iestādē } \\
\text { izturas vienādi }\end{array}$ & 2,78 \\
\hline Darba saturs un darba rezultāti (d) & Man patīk darbs, kuru es daru & 4,18 & Iestādē es jūtos novērtēts & 3,23 \\
\hline Darba vide (e) & $\begin{array}{l}\text { Telpā, kurā es strādāju ir pietiekami } \\
\text { gaišs }\end{array}$ & 4,20 & $\begin{array}{l}\text { Jautājumu risināšana notiek ātri un } \\
\text { elastīgi }\end{array}$ & 3,11 \\
\hline Attiecības ar tiešo vadītāju (f) & Mans vadītājs mani ciena & 3,97 & $\begin{array}{l}\text { Mana vadītāja personālvadības } \\
\text { prasmes ir augstā līmenī }\end{array}$ & 3,40 \\
\hline $\begin{array}{l}\text { Cilvēkresursu plānošana un attīstība } \\
\text { (g) }\end{array}$ & $\begin{array}{l}\text { Man papildus amata aprakstā } \\
\text { noteiktajam tiek uzticēti vienreizēji } \\
\text { darba uzdevumi }\end{array}$ & 3,84 & $\begin{array}{l}\text { Man ir iespēja pilnveidot savas } \\
\text { profesionālās zināšanas un prasmes } \\
\text { ārvalstu komandējumos }\end{array}$ & 2,14 \\
\hline $\begin{array}{l}\text { Darba atalgojums un tā sasaiste ar } \\
\text { rezultātiem (h) }\end{array}$ & $\begin{array}{l}\text { Mani darba rezultāti tiek adekvāti } \\
\text { novērtēti }\end{array}$ & 2,86 & $\begin{array}{l}\text { Man papildus atalgojumam tiek } \\
\text { nodrošinātas arī citas sociālās } \\
\text { garantijas, stimuli }\end{array}$ & 1,79 \\
\hline
\end{tabular}


Kā redzams, tad visaugstākais novērtējums valsts pārvaldes darbinieku vērtējumā ir pieškirts darba vides faktora grupā telpas apgaismojumam ar vērtību 4,20, tad seko apgalvojums no faktoru grupas (d) - darba saturs un darba rezultāti. Visaugstāk - ar 4,18 punktiem - darbinieki šajā faktora grupā ir novērtējuši apgalvojumu - Man patīk darbs, kuru es daru. Savukārt faktora grupā (a) - iestādes līderība un plānošana vislielāko novērtējumu 4,17 punktus ir saṇēmis apgalvojums No darbiniekiem iestādē tiek prasīta atbildība par rezultātiem. Savukārt viszemāko novērtējumu, 2,86 punktus, starp visaugstāk novērtētajiem apgalvojumiem ir saņēmis apgalvojums - Mani darba rezultāti tiek adekvāti novērtēti faktoru grupā (h) - darba atalgojums un tā sasaiste ar rezultātiem. Kopumā šīs faktoru grupas zemais vidējais novērtējums liecina, ka visus apgalvojumus, kas saistīti ar atalgojumu un tā sasaisti ar darba rezultātiem, valsts pārvaldes darbinieki ir vērtējuši vairāk negatīvi nekā pozitīvi. Kopumā šajā faktoru grupā ietvertais apgalvojums arī saņēmis viszemāko darbinieku vērtējumu starp viszemāk novērtētajiem apgalvojumiem. Apgalvojums - Man papildus atalgojumam tiek nodrošinātas arī citas sociālās garantijas stimuli - ir novērtēts ar 1,79 punktiem, kas liecina, ka lielākajai daḷai valsts pārvaldes darbinieku šādas sociālās garantijas šobrīd ir liegtas. Nākamais viszemāk novērtētais apgalvojums ar 2,14 punktiem - Man ir iespēja pilnveidot savas profesionālās zināšanas un prasmes ärvalstu komandējumos - raksturo situāciju faktoru grupā (g) cilvēkresursu plānošana un attīstība. Trešais viszemāk novērtētais apgalvojums ar 2,78 punktiem - Pret visiem darbiniekiem iestādē izturas vienādiir no faktoru grupas (c) - iestādes kultūra un iekšejāā komunikācija. Savukārt faktoru grupā (a) - iestādes līderība un plānošana - viszemāko novērtējumu 2,86 punktus ir sañēmis apgalvojums - Iestādē ir izstrādāta skaidra personāla politika. Kā redzams, tad iepriekš minētais zemais apgalvojumu novērtējums sakrīt ar iepriekš atspoguḷoto kopējo darbinieku viedokli par valsts pārvaldē notiekošo cilvēkresursu politikas plānošanas ieviešanas procesu. Stratēégiskās cilvēkresursu vadības trūkums pamato arī negatīvo tendenci valsts pārvaldes darbinieku viedoklī par darba mainu.

5. attēlā ir atspoguḷots valsts pārvaldes darbinieku viedoklis par iespējamo darba mainu.

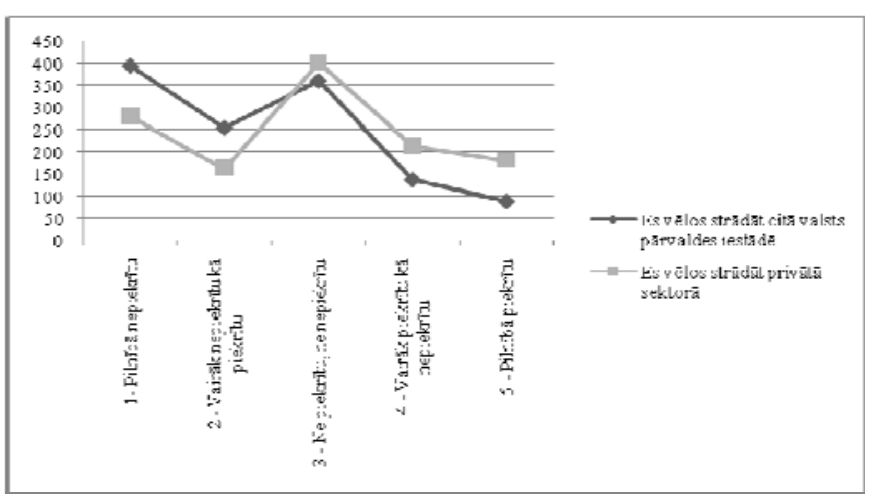

5.att. Valsts pārvaldes darbinieku novērtējums par vēlēšanos strādāt citā valsts pārvaldes iestādē vai privātajā sektorā $(\mathrm{n}=1244)$.
Aptaujas dati liecina, ka vairāk nekā puse jeb 55\% respondentu pēdējā gada laikā ir domājuši par darba mainu. Par darba mainuu vairāk nav domājuši nekā ir tikai $28 \%$ respondentu. No visiem respondentiem vēlēšanos strādāt citā valsts pārvaldes iestādē ir izteikuši $18 \%$ respondentu, bet vēlēšanos strādāt privātajā sektorā $-32 \%$ respondentu.

Darba vides faktoru grupā (e) tika iekḷauti divi apgalvojumi, lai novērtētu darbinieku viedokli par jaunu un inovatīvu darba metožu izmantošanu un par elastīga darba laika nosacījumu ievērošanu valsts pārvaldes iestādēs. Kopumā $52 \%$ respondentu vairāk piekrīt, ka institūcijā tiek ievēroti elastīgi darba laika nosacījumi. Attiecīgi apgalvojums - Iestādē tiek ievēroti elastīga darba laika nosacījumi - tika novērtēs ar 3,26 punktiem. Savukārt apgalvojums - Iestādē tiek izmantotas jaunas un inovatīvas darba metodes - tika novērtēts zemāk, t.i., ar 3,21 punktu. Kopumā mazāk kā puse jeb 45\% respondentu vairāk piekrīt, ka institūcijas darbā tiek izmantotas jaunas un inovatīvas darba metodes. Turpretī $27 \%$ respondentu šãdam apgalvojumam nepiekrīt.

Nākamajā apkšsadal̦ā tiek atspoguḷots darbinieku novērtējums tādai jaunai darba organizācijas formai kā attālinātais darbs. Šis novērtējums parāda, ka ar jaunu un inovatīvu darba organizācijas metožu ieviešanu un izmantošanu valsts pārvaldes institūcijās ir vēl bēdīgāk, nekā valsts pārvaldes darbinieki ir vērtējuši iepriekš.

\section{Valsts pārvaldes darbinieku novērtējums par attālinātā darba ieviešanas potenciālu valsts pārvaldē}

Attālinātais darbs ir darba organizācijas forma, kura ḷauj darbiniekiem strādāat attālināti un veikt savus darba pienākumus, neatrodoties darba vietā. Šādu darba organizācijas formu arvien vairāk pasaulē izmanto intelektuālā darba veicēji, pie kuriem būtu pieskaitāmi arī valsts pārvaldes darbinieki. 6.attēlā ir atspoguḷots valsts pārvaldes darbinieku vērtējums par attālinātā darba attīstību valsts pārvaldes iestādēs.

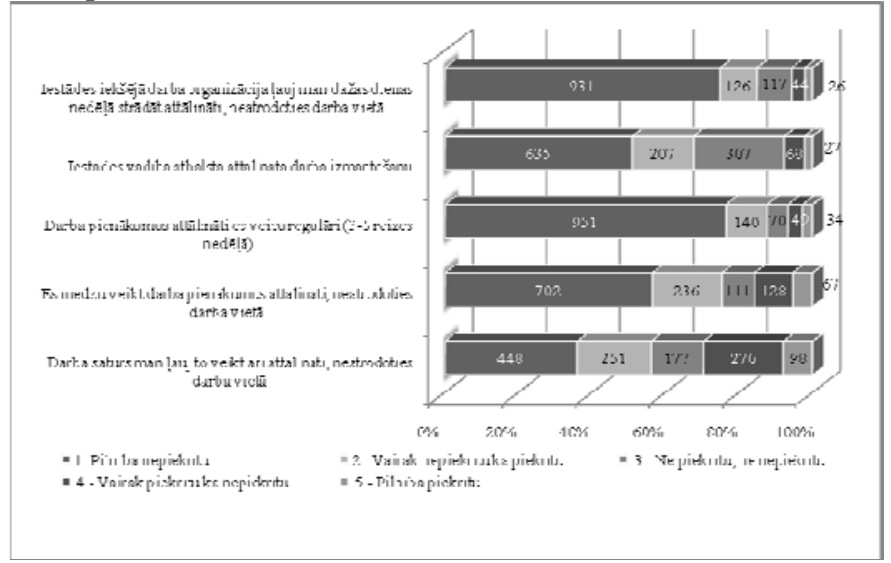

6.att. Valsts pārvaldes darbinieku viedoklis par attālinātā darba attīstību valsts pārvaldes institūcijās ( $\mathrm{n}=1244)$.

Šis jautājums tika iekḷauts anketā, lai noskaidrotu, vai un cik bieži šāda darba organizācijas forma tiek izmantota valsts pārvaldē, nuemot vērā, ka šādas darba organizācijas formas izmantošana var būt papildu motivators darbiniekiem, kā arī radīt sociāli ekonomiskus ieguvumus valsts pārvaldē kopumā. Diemžēl aptaujas rezultāti liecina, ka attālinātais darbs valsts 
pārvaldē tiek izmantots l,oti reti. Darbinieki uzskata, ka to nel̦auj darīt veicamais darba saturs un iestādes iekšējā darba organizācija. Vairāk nekā puse jeb 56\% respondentu nepiekrīt apgalvojumam, ka darba saturs to l̦auj veikt attālināti, neatrodoties darba vietā. Ievērojams skaits jeb $76 \%$ respondentu norāda, ka nemēdz veikt darba pienākumus attālināti, neatrodoties darbvietā, un vēl lielāks skaits - 87\% respondentu nepiekrīt apgalvojumam, ka darba pienākumus attālināti veic regulāri 3-5 reizes nedēlāa. Tāpat $68 \%$ respondentu norāda, ka iestādes vadība neatbalsta attālināta darba izmantošanu, un 85\% respondentu apgalvo, ka iestādes iekšējā darba organizācija nel̦auj darbiniekiem dažas dienas nedēlāa strādāt attālināti, neatrodoties darbvietā. Tomēr darbinieku viedoklis par šādas darba organizācijas formas attīstības iespējām parāda, ka tai ir potenciāls.

7.attēlā ir atspoguļots valsts pārvaldes darbinieku viedoklis par attālinātā darba attīstības potenciālu un ietekmi uz darbinieku motivāciju. Apkopotā informācija liecina, ka lielākais vairums respondentu šādu iespēju izmantotu, ja tāda būtu. Tāpat ievērojams skaits aptaujāto norāda, ka šāda darba organizācijas forma darbiniekos radītu papildu motivāciju uzlabot savu sniegumu. Vairāk nekā puse jeb 63\% respondentu norāda, ka izmantotu iespēju savu darbu darīt attālināti, ja tāda tiktu dota. Savukārt šādu iespēju neizmantotu $23 \%$ respondentu.

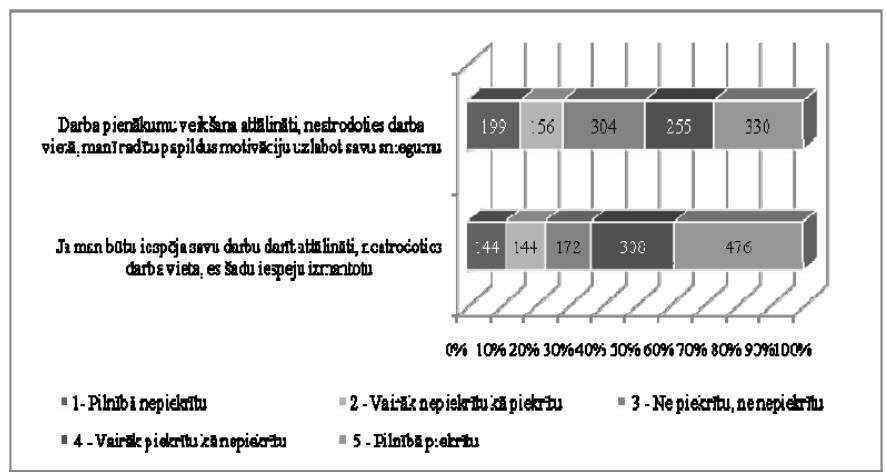

7.att. Valsts pārvaldes darbinieku viedolis par attālinātā darba attīstības potenciālu un ietekmi uz darbinieku motivāciju $(\mathrm{n}=1244)$.

47\% respondentu darba pienākumu veikšana attālināti radītu papildu motivāciju uzlabot sniegumu. Tam nepiekrīt $29 \%$ respondentu, bet tie, kuri šādam apgalvojumam ne piekrīt, ne nepiekrīt, sastāda $24 \%$ no visiem aptaujātajiem valsts pārvaldes darbiniekiem.

\section{V.SECINĀJUMI}

Esošais situācijas novērtējums uzskatāmi parāda, ka valsts pārvaldē strādājošajiem šobrīd nav skaidrs institucionālais un funkciju dalījums valsts pārvaldes cilvēkresursu politikas plānošanas un ieviešanas jomā un ka valsts pārvaldē nenotiek mērktiecīga cilvēkresursu politikas plānošana un ieviešana. Tādējādi jāsecina, ka valsts pārvaldē nav pietiekami attīstīta stratēǵiskā cilvēkresursu vadība, kas noved pie formālas personāla vadības funkciju īstenošanas. To parāda arī situācijas vērtējums konkrētajās iestādēs, jo cilvēkresursu plānošanas un attīstības aspektus attiecīgajā iestādē darbinieki vērtē samērā negatīivi. Aptaujas rezultāti liecina, ka iestādēs netiek veikti pêtījumi par darbinieku apmierinātību ar darbu un apmierinātîbas novērtējums netiek n,emts vērā iestādes personāla politikas plānošanā. Tāpat tiek atzīts, ka darbinieku ikgadējā novērtēšana ir vairāk formāla nekā lietderīga un ka novērtēšanu rezultāti netiek ņemti vērā personāla politikas uzlabošanā. Tādējādi jāsecina, ka šobrīd iestādēs nepietiekami tiek izmantoti dažādi cilvēkresursu plānošanas, vadības un motivācijas rīki.

Darbinieku vērtējums par valsts pārvaldes cilvēkresursu politikas plānošanas un ieviešanas aspektiem iespējams būtu jāskata kontekstā ar finanšu krīzes rezultātā piencemtajiem fiskālās konsolidācijas pasākumiem, kuri lielā mērā bija vērsti uz valsts pārvaldes izdevumu samazināšanu. Rezultātā tika veikti gan institūciju optimizācijas pasākumi, gan darbinieku skaita samazināšana valsts pārvaldes iestādēs un atalgojuma samazinājums valsts pārvaldes darbiniekiem. Piemēram, funkciju pārskatī̌sanas rezultātā tika likvidēta civildienesta pārvalde, tās funkcijas nododot Valsts kancelejai un Finanšu ministrijai, tāpat daudzās iestādēs tika apvienotas tādas atbalsta funkcijas kā personāla vadība, lietvedība un finanšu vadība, mazinot personālvadības lomu iestādes plānošanā un rezultātu nodrošināšanā.

Darbinieku apmierinātību ietekmējošo faktoru novērtējums parāda tās jomas, kuras šobrīd valsts pārvaldes institūcijās būtu vērtējamas kā pozitīvie motivatori, piemēram, darba saturs un darba vide. Lai gan valsts pārvaldes darbinieku vērtējumā darba saturs ir loti būtisks aspekts, kas ietekmē darbinieku apmierinātību ar darbu, tomēr darba rezultātiem neatbilstošais atalgojums veicina darbiniekus domāt par darba maiņu.

Tādēḷ valsts pārvaldē un iestādēs attiecībā uz cilvēkresursu vadības un ieviešanas aspektiem ir nepieciešama domāšanas maiņa, kur cilvēkresursu vadības jautājumi tiek skatīti ne tikai izmaksu samazināšanas kontekstā, bet gan valsts pārvaldes un iestāžu efektivitātes kontekstā. Lai situācija nepasliktinātos vēl vairāk, ir jāveic tūlītējus pasākumus, izmantojot darbinieku motivēšanā tos faktorus, kuri pozitīvi ietekmē darbinieku apmierinātību, un, izstrādājot pasākumu plānus, kas būtu veicami, lai uzlabotu darbinieku apmierinātību ar tādiem faktoriem kā cilvēkresursu plānošana un attīstība, kā arī darba atalgojums un tā sasaiste ar rezultātiem.

Attālinātā darba kā darba organizācijas novērtēšanas rezultāti arī parāda stratēgiskā skatījuma uz cilvēkresursu ieviešanas aspektiem trūkumu valsts pārvaldē. Tādējādi attālinātais darbs parāda potenciālu nākotnes cilvēkresursu politikas plānošanā, ieviešot jaunas un inovatīvas darba organizācijas formas un metodes, kas varētu uzlabot darbinieku apmierinātību un darba rezultātus.

\section{LITERATŪRAS SARAKSTS}

[1] Peter Wilson AM, The Future of Work and the Changing Workplace: Challenges and Issues for Australian HR Practitioners, 
people@work/2020 Australian Human Resources Institute, May 2010, [Online]. Available: http:/www. ahri.com.au/MMSDocuments/../research/.../fow_white_paper.pdf [Accessed: August. 02, 2012].

[2] OECD Policy Brief ,Public Sector Modernisation: Modernising Public Employment", OECD July 2004, [Online]. Available http://www.oecd.org./publications/Pol brief. [Accessed: August. 02, 2012].

[3] Chanda, Ashok, Shen, Jie HRM Strategic Integration and Organizational Performance, 2009, p.73.-94.

[4] Vijaya Mani, Development of Employee Satisfaction Index Scorecard European Journal of Social Sciences - Volume 15, Number 1 (2010), p.129-139.

[5] http://www.humanresources.hrvinet.com/what-is-employee-satisfactionindex-esi/

[6] Brayfield, A. H., \& Rothe, H. F. (1951). An index of job satisfaction. Journal of Applied Psychology, 35, 307-311. http://dx.doi.org/10.1037/h0055617

[7] McLeod, S. A. (2008). Likert Scale. Retrieved from http://www.simplypsychology.org/likert-scale.html

Iveta Baltina obtained a degree of Master of Social Sciences in 2002 at the University of Latvia. Since September 2010 she has been pursuing a doctoral degree at Riga Technical University. At present, the author works as a Researcher and Independent Consultant. In 1999 she started her professional career as a Senior Officer at the Ministry of Finance of the Republic of Latvia. From 2004 to 2007 she was dealing with EU financing as a Head of EU Funds Department of the Ministry of Finance of the Republic of Latvia. Finally, from 2007 to 2010 she was a Head of municipal institution, responsible for administration of local government. The previous studies were carried out on the issues of EU regional policy and structural funds implementation system. The doctoral studies will be performed in the field of Public Administration to carry out an in-depth analysis of structural reforms in the Public Administration and to work on its optimisation.

E-mail: iveta.baltina@rtu.lv

Maija Šenfelde holds a degree of Doctor of Economics (1993) from the Scientific Council of Latvian University. She has been working for Riga Technical University in different positions. Since 2003 Maija Šenfelde has been a Professor at the Faculty of Engineering Economics and Management. Since 2009 she has been a Head of the Institute of National and Regional Economy. From 1997 to 2007 she was a Deputy Dean for Studies. Main fields of research are macroeconomics, international and regional economics. She has published scientific papers in peer-reviewed journals and articles. Also, she is the author of textbooks. Maija Šenfelde is an Expert of the Latvian Council of Science, Member of Promotion Council, Member of Professors' Councils of RTU and LU etc.

E-mail: maija.senfelde@rtu.lv

Iveta Baltina, Maija Šenfelde. The Assessment of Human Resource Management Policy in Public Administration of Latvia and the Perspectives for its Development

In the situation when great emphasis is placed on effectiveness of public administration it is important to estimate current strengths and weaknesses of human resource development (HRD) in public administration of Latvia, as well as assessing whether HRD activities ensure a strategic perspective in the light of rapid changes in economy and labour market, as well as with pressure of society for small and effective public administration. Since one of the factors influencing organization performance is employee satisfaction and motivation then the purpose of this article is to assess the level of satisfaction of public employees with current HRM policy planning and implementation as well as with the working environment in the public institution. A combination of qualitative and quantitative methods was applied to assess public employees' attitude to public administration HRM policy in Latvia and to assess public employees' satisfaction rate with the working environment in a respective public institution. The survey shows that public employee's do not have a clear institutional and functional setup in the HRD policy planning and implementation in the public administration of Latvia. The HR system focuses on the performance of administrative functions, but the strategic dimension of HR planning and implementation is missing. Assessment of the factors influencing employee satisfaction with the working environment in a respective institution shows that content of the job and working environment are most positively valued in comparison with HR planning and development and the linkage between pay and performance, which got the lowest scores in the assessment of eight factors.

Ивета Балтиня, Майя Шенфелде. Оценка политики управления человеческими ресурсами в государственном управлении Латвии и возможности её совершенствования.

В условиях возрастания значения эффективности госуправления необходимо оценить сильные и слабые стороны политики управления человеческими ресурсами, занятыми в данной сфере, а также определить, какие мероприятия по её развитию являются перспективными в условиях значительных перемен как в экономике в целом, так и на рынке труда. Кроме того, необходимо принять во внимание, что для общества требуется компактное и эффективное госуправление. Так как одним из факторов, влияющим на результат деятельности, является мотивация и удовлетворение работающих, то целью данной статьи явилась оценка удовлетворенности занятых в госуправлении настоящей политикой управления человеческими ресурсами, её планированием и реализацией, а также их условиями труда. Методы качественного и количественного анализа были применены для оценки отношения работающих к политике управления человеческими ресурсами в госуправлении Латвии и к их удовлетворённости условиями труда в соответствующем учреждении. Анализ показал, что занятые в госуправлении не имеют чёткого представления о данной политике, она реализуется весьма формально и не направлена на стратегические цели. Работающие более удовлетворены содержанием и условиями труда, чем политикой развития и мотивации человеческих ресурсов, а определяющее влияние результата труда на его оплату получило самую низкую оценку в результате опроса среди восьми оцениваемых факторов. 